\title{
MEMASUKI MILLENIUM KE III \\ DENGAN GAYA KEPEMIMPINAN YESUS \\ (GAYA KEPEMIMPINAN 2000 TAHUN LALU)
}

$\underline{P d t}$. Dr. Peter Anggu

Jika seorang pendeta diminta untuk memberikan ceramah biasanya ia mulai ceramah dengan mengutip ayatayat Alkitab, mungkin agar supaya ceramah itu dianggap ceramah resmi seorang rohaniawan. Sayangnya biasa ceramah tersebut berubah sifatnya sehingga sulit membedakannya dengan sebuah khotbah. Begitu pula seorang pakar non pendeta yang diminta berceramah di kalangan rohaniawan adakalanya juga mengawali ceramahnya dengan kutipan ayat-ayat Alkitab, mungkin agar supaya penceramah itu dianggap cocok dengan para rohaniawan. Menyimpang dari kebiasaan tersebut, ceramah ini tidak diawali dengan pembacaan ayat-ayat Alkitab melainkan kutipan pernyataan seorang direktris perusahaan besar yang mengatakan:

Saya yakin dunia sedang menjerit meminta para pemimpin yang bertujuan membangun, bukan untuk menghancurkan, untuk menghidupi dan bukan untuk memeras, untuk mendukung dan memperkuat, bukannya malah mendominasi. Di mata saya Yesus adalah yang teragung di antara segala pemimpin saya percaya gaya manajemen 'Omega' Yesus memadukan dan mengatasi yang. terbaik dari gaya kepemimpinan... sebab dengan mengendalikan energi spiritual, kita masing-masing, baik pria maupun wanita, bisa diberdayakan menjadi pemimpin yang dibutuhkan oleh abad mendatang ${ }^{2}$

Laurie Beth Jones dalam bukunya yang berjudul Jesus, Chief Executive Officer, satu buku yang terlaris di Amerika Serikat pada tahun 1995 menekankan bahwa Yesus yang hidup 2000 tahun lalu mem- punyai gaya kepemimpinan yang luar biasa yang masih sangat relevan diterapkan pada masa kini. Saya mempunyai pendapat yang sama sehingga ceramah ini saya beri judul, Memasuki Millenium ke III dengan gaya kepemimpinan Yesus yaitu kepemimpinan 2000 tahun lalu. Judul ini pasti menimbulkan tanda tanya besar yaitu apakah kepemimpinan yang dipraktekkan 2000 tahun lalu tidak kolot sehingga masih mempunyai relevansi untuk diterapkan pada millenium ke III di mana segala sesuatunya telah dipengaruhi dan dikuasai oleh kemajuan dan perkembangan ilmu pengetahuan dan teknologi yang sangat mutakhir. Dengan menyimak gaya hidup dan pola kerja Tuhan Yesus sebagaimana dipaparkan oleh penulis-penulis Injil maka saya mempunyai keyakinan pertanyaan ini akan dapat dijawab secara positif melalui pembahasan-pembahasan dalam ceramah ini. Menurut pengamatan saya bahwa pola hidup dan gaya Yesus dalam melaksanakan karya-Nya di dunia ini sangat luar biasa dan tidak ada tandingannya yang berlaku baik dari dahulu sekarang dan masa yang akan datang, sehingga tetap sangat relevan untuk dijadikan pedoman dalam pergumulan kepemimpinan gereja memasuki millenium yang ke III ini.

Berdasarkan latar belakang pokok pemikiran di atas, maka ceramah ini akan dirangkai dalam beberapa pokok bahasan sebagai berikut:

1. Pemahaman tentang Millenium ke III

2. Gaya kepemimpinan Yesus

3. Relevansi kepemimpinan Yesus 


\section{Pemahaman tentang Millenium ke III}

Istilah millenium sangat populer akhir-akhir ini dengan pemahaman arti dan makna yang saling berbeda satu daripada yang lain. Di pasar-pasar, di tokotoko bahkan di jalan-jalan serta melalui pelbagai mas media kita jumpai kata millenium sebagai merek dari suatu produk, misalnya motor millenium, sepatu millenium, dsb. Ada hotel millenium, warna millenium, film millenium, dsb. Apakah yang dimaksudkan dengan millenium dalam pemakaian-pemakaian tersebut. Saya menduga bahwa millenium di sini berarti sesuatu yang baru, sesuatu yang hebat dan sesuatu yang lain dari yang lain.

Secara teologis kata millenium dipahami sebagai suatu kerajaan yaitu kerajaan 1000 di mana oleh penganut paham premillenialisme diyakini bahwa Yesus Kristus akan datang kedua kali ke dunia ini untuk mendirikan kerajaan 1000 tahun. Suatu kerajaan di dunia yang akan mengalami suasana tenteram dan damai karena Kristus sendiri yang menjadi raja. Aliran post millenialisme di pihak lain berpendapat bahwa millenium adalah suatu keadaan di mana Kristus dirajakan dan menjadi raja di dalam hidup orang percaya, bukan suatu kerajaan yang riel yang akan diwujudkan di atas muka bumi ini. Kerajaan ini telah, sedang berlaku sekarang ini.

Sekarang timbul pertanyaan, mengapa millenium ke III. Dari mana perhitungan ketiga itu diperoleh. Ada beberapa kemungkinan (1) Millenium itu terkait dengan Kristus sehingga perhitungannya dimulai tahun pertama sesudah Yesus datang ke dunia ini untuk pertama kalinya sekitar dua ribu tahun yang lalu. (2) Millenium ke III dapat diganti menjadi millenium ke VII. Kaum Despensasionalis menggambarkan peta sejarah umat manusia dalam analogi penciptaan alam semesta ini. Bahwa enam hari lamanya Tuhan menciptakan alam semesta ini dan berhenti pada hari ketujuh. Sejarah perkembangan manusia dihitung mulai dari Adam sampai dengan Nuh 2000 tahun dari Nuh sampai dengan Kristus 2000 dan dari Kristus sampai sekarang sesudah 2000 tahun. Ini berarti bahwa sejak dari Adam sampai sekarang telah terdapat enam kali seribu tahun dan sekarang kita masuk ke dalam seribu tahun ketujuh. Dari perhitungan itu dapat dikatakan bahwa memasuki millenium ke III sama dengan memasuki millenium ke VII. (3) Millenium ke III adalah akhir zaman. Berdasarkan kegenapan nubuatan dan janji-janji tentang kedatangan Yesus yang kedua kali maka jelas bahwa sekarang kita telah berada pada masa akhir zaman. Jadi millenium adalah akhir zaman dan kondisi akhir zaman adalah suatu masa yang sukar sulit (2 Tim 3:1-5).

Berdasarkan fakta-fakta di atas dapat disimpulkan bahwa millenium ke III tidak lain dari suatu akhir dari masa dunia ini yang ditandai dengan timbulnya berbagai gejolak yang belum pernah terjadi sebelumnya yang sangat perlu diwaspadai dengan sebaik-baiknya.

\section{Gaya Kepemimpinan Yesus}

Jika kita menelusuri kehidupan Kristus selama Ia ada di atas bumi ini yang dipaparkan oleh penulis Injil dari segi gaya dan pola kepemimpinannya maka kita akan menemukan sekurang-kurangnya ada tiga hal yang menjadi karakteristik dari kepemimpinan yang dipraktekkan oleh Yesus yang nampak dalam sikap dan pandangan-Nya terhadap dirinya, sikap dan pandangannya terhadap tugas dan misi-Nya serta sikap dan relasinya terhadap orang lain.

\section{Gaya kepemimpinan Yesus melalui cara melihat diri-Nya sendiri.}

Ada begitu banyak gambaran yang ditampilkan oleh Yesus mengenai diri-nya 
yang justru mengungkapkan rahasia kekuatan kepemimpinan yang dimilikinya melalui penguasaan diri.

1. Bersikap positif terhadap dirinya. Kita jumpai bahwa Yesus berulang kali mengatakan "Akulah..." itu bukan berarti Ia sombong dan sangat egois tetapi sesungguhnya Ia menyatakan secara positif siapa dia sebenarnya. Yesus mempunyai citra diri yang positif.

2. Memahami dengan benar tentang posisi dan tanggung jawabnya. Yesus tahu siapa bosnya yang kepadanya setiap saat ia harus bertanggung ja-wab dan membina hubungan kontak yang baik.

3. Yesus mempunyai kepercayaan diri yang kokoh. Ungkapan-ungkapan Yesus, "Akulah gembala bagi dombadomba", "Akulah pintu", "Akulah kebun anggur", dsb. Bukan menunjukkan kecongkakkan tetapi bukti percaya diri bahwa ia dapat berbuat dan menghasilkan sesuatu yang berguna. Arogansi berbeda dengan kepercayaan diri.

4. Pernyataan Yesus "Aku tahu dari mana aku datang dan kemana aku pergi" menunjukkan bahwa Yesus menyadari sepenuhnya tujuan hidupnya. Menyadari tujuan hidup merupakan penginderaan masa depan yang bagi seorang pemimpin merupakan suatu kunci kepemimpinan karena itu merupakan sumber ilham bagi seorang pemimpin yang baik.

5. Keunggulan kepemimpinan Yesus terletak pada tekadnya untuk mempertahankan komitmennya, meskipun dalam situasi yang sangat menekan. Saya menyebut hal itu sebagai kepemimpinan yang nekat-nekatan.

6. Yesus bersedia nampak konyol demi tugas dan misinya. Kepemimpinan Yesus ditandai di satu sisi dengan kerelaan pengorbanan diri dan kepentingannya demi kebahagiann orang lain, tetapi di sisi lain Ia bukan konyol melainkan membuat dia mendapat nama di atas segala nama.

7. Dalam keadaan manusia, Yesus menyadari tentang keterbatasannya, sehingga Ia juga menjaga stamina dirinya dengan waktu-waktu yang dipilih untuk sendirian dan beristirahat untuk memulihkan semangatnya.

8. Yesus tahu menghargai apa yang dipertanggungjawabkan kepadanya dan berterima kasih atas hal-hal yang pernah diterimanya.

\section{Sikap Yesus terhadap tugas-Nya}

Kekuatan gaya kepemimpinan Yesus terletak pada sikap dan tindakannya yaitu bagaimana Yesus secara konsekuen membuktikan apa yang diucapkannya melalui tindakan-tindakan yang nyata. Dalam hal ini Yesus membuktikan pada tindakannya tentang satunya kata dan perbuatan. Sesuatu yang nampaknya sangat langka dan mahal ditemukan di kalangan pemimpin-pemimpin masa kini.

1. Yesus bekerja melalui rencana dan tindakan. Rencana dan tindakan merupakan dua hal yang sangat menentukan keberhasilan. Memang ada orang yang pandai berencana, tetapi tidak pandai melaksanakannya dan sebaliknya ada orang yang bersemangat untuk bekerja tetapi di luar rencana. Rencana yang terwujud dalam pelaksanaan menghasilkan gaya kepemimpinan yang solid dan meyakinkan. "Buatlah rencana dan laksanakan rencana itu".

2. Yesus melihat segala sesuatu sebagai sumber potensi yang bermakna untuk menemukan kehidupan, kekurangan air anggur di pesta perjamuan kana merupakan kesempatan mendemonstrasikan mujizatnya pertama. Kema- 
tian Lazarus merupakan momen yang bermanfaat untuk Yesus menunjukkan kasih dan kuasanya.

3. Dalam melaksanakan tugasnya Yesus menggunakan prinsip "detol (dengan dan tanpa orang lain". Yesus senang bersama dan bekerjasama dengan orang lain. Tetapi adakalanya tanpa orang lain Yesus tetap mampu bekerja.

4. Yesus menerapkan prinsip langkah demi langkah, meskipun adakalanya kelihatannya terlambat dan menjemukan. Yesus tahu bahwa kematian harus mendahului kebangkitan, salib harus mendahului kemuliaan, meskipun ada orang yang ingin semuanya serba instant.

5. Yesus merepotkan diri demi kepentingan orang lain. Ia mempunyai kesetaraan dengan Allah tidak merasa puas dengan itu melainkan menghampakan diri, mengambil tempat seorang hamba yang melayani dan menjadi sama dengan manusia.

6. Ia melatih dan mempersiapkan orang lain untuk meneruskan tugas ketika ia harus kembali kepada Bapa. Ia tahu bahwa waktunya di dunia terbatas sedang pekerjaannya tidak akan berakhir pada waktu ia telah pergi.

7. Yesus mampu mengatasi masalah. Yesus digambarkan sebagai seorang yang penuh derita dan sengsara serta akrab dengan kesusahan, tetapi Yesus tidak membiarkan masalah untuk menghancurkan misi dan tugasnya.

8. Ia tahu bahwa Ia tidak bekerja sendirian. Yesus mengerti bahwa selam di dunia ia tidak sendirian sehingga pada saat Ia tergantung di kayu salib Ia berteriak, Ya, Allahku, ya Allahku mengapa Engkau meninggalkan aku?

9. Yesus adalah arsitek perubahan. Dalam khotbahnya di Bukit Ia mengkritik habis-habisan pola lama dan menegaskan tentang pola hidup baru.

\section{Gaya Kepemimpinan Yesus tercermin dalam relasinya dengan orang lain}

Kategori gaya kepemimpinan Yesus yang ketiga ialah perwujudan kekuatan melalui relasi, yaitu bagaimana menempatkan diri dalam komunikasi dengan orang lain. Kepemimpinan tanpa di dukung komunikasi yang baik akan lumpuh total.

1. Yesus bersikap transparan, yaitu membuka dirinya bagi orang-orang lain dan memperhatikan orang lain dengan segala keperluannya.

2. Ia percaya kepada orang lain dengan melihat hal yang positif yang ada pada orang lain itu dan kemudian mempercayakan tugas dan tanggung jawab kepada mereka.

3. Ia mendidik dan melatih orang lain untuk mempersiapkan orang-orang itu sebagai penggantinya.

4. Ia memberdayakan orang lain karena Ia tahu bahwa setiap orang mempunyai potensi yang dikaruniakan Allah kepadanya. Bayangkan Ia memanggil pemungut cukai untuk menjadi pengikut-Nya.

5. Ia menyediakan waktu cukup untuk bersama dengan orang lain untuk berdiskusi dan berdoa.

6. Ia memberi simpati kepada semua orang, yaitu kepada orang yang terabaikan, tetapi juga memberikan perhatian kepada khalayak ramai dan menjamu mereka yang dalam keadaan kelaparan.

7. Ia mengasihi dan rela berkorban demi kepentingan orang lain tanpa memperhitungkan berapa pun harganya. Ia mengasihi sampai pada akhir hayat-Nya.

8. Mungkin la sering bercanda dengan para stafnya untuk memberikan gairah dan semangat pada waktu mereka sedang dalam situasi yang tegang dan menakutkan. 
9. Ia memandang manusia sebagai manusia, bukan sebagai benda dan memperlakukannya sebagai bagian dari diri-Nya sendiri.

10. Ia memandang orang lain sebagai sukses yang tidak ada taranya dengan berkata "Aku telah dipermuliakan di dalam mereka". Dalam laporan Tuhan Yesus melalui doanya dalam Yohanes 17 Ia tidak menyebutkan tentang sukses mengubah air menjadi anggur, mujizat melipatgandakan roti dan anggur untuk orang banyak. Ia juga tidak menyebutkan bahwa Ia telah membangkitkan sekian orang mati, melainkan orang-orang yang telah diserahkan kepadanya yang Ia cintai dan tetap Ia doakan.

\section{Relevansi Kepemimpinan Yesus memasuki Millenium ke III}

Setelah mengungkap sebagian dari rahasia kepemimpinan Yesus ini kita akan mencoba mengaplikasikannya melalui tantangan kepemimpinan di millenium ke III. Dengan memahami kondisi millenium ke III sebagai millenium akhir zaman yang ditandai sebagai masa yang sukar sulit maka dengan berpedoman kepada kepemimpinan Yesus berikut ini akan dikemukakan bentuk atau corak kepemimpinan yang diharapkan dapat menjawab tantangan kepemimpinan gereja masa kini.

1. Kepemimpinan yang mampu mempertahankan spiritualitas sebagai kunci kepemimpinan Gereja di zaman modern ini. Setiap pemimpin gereja harus mampu membuktikan dengan kata dan tindakan bahwa ia adalah pemimpin rohani.

2. Kepemimpinan yang mampu menjembatani dua kutub yang berjauhan yaitu antara sorga dan dunia dengan prioritas yang seimbang tanpa mengorbankan salah satu di antaranya.
3. Kepemimpinan yang bisa bertahan hidup (Survive) di tengah-tengah dunia yang mengglobal dengan daya persaingan yang ketat. Untuk itu dibutuhkan pemimpin-pemimpin yang mempunyai nilai tambah sehingga masih dapat dikategorikan sebagai pemimpin-pemimpin yang unggul.

4. Kepemimpinan yang mampu melihat dan menggunakan perbedaan-perbedaan persepsi bahkan doktrin sebagai sarana untuk membina kerjasama yang lebih efektif.

5. Kepemimpinan yang sadar waktu sehingga tidak membuang-buang kesempatan dengan sibuk mengurus hal-hal yang sepele dan mengabaikan kesempatan-kesempatan emas yang ditawarkan.

6. Kepemimpinan yang mampu memanfaatkan IPTEK modern, sehingga tidak merupakan pemimpin yang ditinggalkan oleh zamannya. Kita sekarang sedang berada pada kecenderungan era urbanisasi modern di mana bukan orang-orang desa berbondong-bondong datang ke kota tetapi gaya hidup kota yang dipacu oleh perkembangan ilmu pengetahuan dan teknologi modern akan mendesak dan menyusup sampai ke desa-desa dengan gaya dunia modern yang berkembang di kota-kota. Jangan ketinggalan.

\section{Penutup}

Dari apa yang telah dipaparkan di atas dapat kita simpulkan bahwa kepemimpinan Yesus walaupun telah 2000 tahun laiu, masih cukup relevar untuk dijadikan acuan untuk menghadapi tantangan kepemimpinan Gereja. memasuki millenium yang ke III. 
Referensi:

Engstrom, Ted. W. dan Dayton, Edward $\mathrm{R}$. The Art of Management for Christian Leaders. Texas: Words Book, Publisher, 1976.

Jones, Laurie Beth. Jesus Chief Executif Officer. Jakarta: Mitra Utama, 1997.

Swindoll, Charles R. Kepemimpinan Kristen yang Berhasil. Surabaya: Yakin, Majalah Kepemimpinan, vo. 39 tahun $X$.

\section{(Footnotes)}

${ }^{1}$ Ceramah pada perayaan Yubelum STT KIBAID Makale 22 Juni 2001.

${ }^{2}$ Laurie Beth Jones, Jesus Chief Executive Officer (Jakarta: Penerbit Mitra Utama, 1997), iv.
Pdt. Dr. Peter Anggu

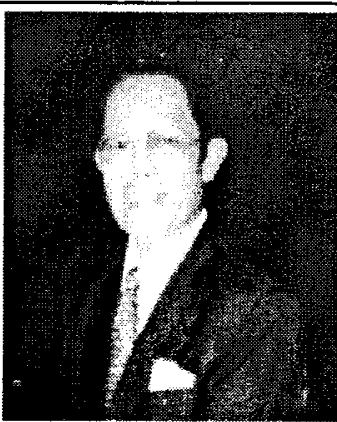

Dosen STT Jaffray dan Mantan Ketua STT Jaffray, selama 18 Tahun 